\title{
Evaluation and management of precocious puberty
}

\author{
Navoda Atapattu ${ }^{1}, \mathrm{~K}$ S H de Silva ${ }^{2}$ \\ Sri Lanka Journal of Diabetes, Endocrinology and Metabolism 2013; 3: 76-79
}

\begin{abstract}
Puberty is an important event in adolescence. Altered timing of puberty brings about anxiety and fears in both the child and parents. Precocious puberty is usually idiopathic in a girl whereas a secondary cause needs to be excluded in a boy. Diagnosis and management require a careful evaluation in a logical sequence. The normal variants of puberty may not need extensive investigations but child will have to be followed up. The diagnostic and therapeutic approaches to a child with precocious puberty are discussed in this article.
\end{abstract}

\section{Introduction}

Puberty is the process of physical, hormonal and psychological changes in a child's body facilitating the reproductive capabilities. Pubertal changes are triggered by sex hormones following activation of the hypothalamo pituitary gonadal axis.

Genetic and environmental factors are implicated in the timing of puberty (1). Human studies have shown a relationship between body mass index or body fat, dietary and physical activity with the timing of puberty $(2,3,4)$. More recently a G-protein coupled receptor, GPR54 and its ligand Kisspeptin have been identified as important signals in pubertal induction (5). The role of leptin in the pubertal induction is permissive rather than definitive and there are many unanswered questions in relation to role of leptin (6).

\section{Precocious puberty}

Precocious puberty has been traditionally defined as development of secondary sexual characteristics before 9 years in a boy and before 8 years or menstruation before 9.5 years in a girl. However there has been a secular trend towards early pubertal development (7).

Based on 1997 Pediatric Research in Office Settings (PROS) network study Kaplowitz and Oberfield (8) recommended to reset the age limit for precocious puberty to breast development at 7 years in Caucasian girls and 6 in African-Americans. However, due to the dissociation of age of breast development and age at menarche, this opinion was not accepted by many. A recent review by
Midyett et al (9) reported $12 \%$ of black girls to have non idiopathic sexual precocity between 6 and 8 years.

There are two types of precocious puberty.

1. Gonadotrophin dependent precocious puberty (CPP) or central/ true precocious puberty.

This is when pubertal signs are consonant but may be more rapid in progression than in normal puberty.

2. Gonadotrophin independent precocious puberty or sexual precocity.

This is diagnosed when there is no activation of the hypothalamo pituitary gonadal axis and signs of puberty are not consonant.

\section{Diagnosis}

A detailed history is a prerequisite in the diagnosis and management of a child with precocious puberty. If more than one pubertal signs are present and growth is accelerated with advanced bone age, investigations are needed to confirm the diagnosis. In isolated vaginal bleeding the possibility of sexual abuse, foreign body or nonspecific vaginitis should be considered. Exposure to exogenous oestrogen in the form of creams, pills should also be excluded.

Pubertal staging, anthropometry, presence of café au lait patches and examination of the systems including testes are important aspects in the examination.

The height should be compared with the mid parental height and heights of siblings.

${ }^{1}$ Consultant Paediatric Endocrinologist, Lady Ridgeway Hospital for Children, ${ }^{2}$ Professor in Paediatrics, Department of Paediatrics, Faculty of Medicine, University of Colombo, Sri Lanka. 
The following investigations are indicated to confirm the clinical diagnosis of precocious puberty

1. Bone age

Bone age is advanced in precocious puberty but may be delayed in gonadotrophin independent precocious puberty due to untreated hypothyroidism (Van WykGrumbach syndrome) (10).

On average, bone age is 10.75 years at the onset of puberty and 13 years at menarche. Testicular volume of $4 \mathrm{ml}$ is seen at the bone age of 11.5 years (11).

2. Sex hormone levels

Testosterone $>25 \mathrm{ng} / \mathrm{dl}$ or oestradiol $>10 \mathrm{pg} / \mathrm{ml}$ are suggestive of precocious puberty.

If the oestradiol levels are in the upper end of normal range $(75 \mathrm{pg} / \mathrm{ml})$, it is necessary to exclude an ovarian or adrenal tumour (12).

3. Gonadotrophin releasing hormone (GnRH) stimulation test.

The response after 20 and 60 minutes of intravenous 100ug of GnRH can be used to differentiate the two types of precocious puberty. Luteinising hormone (LH) predominant response will be seen in gonadotrophin dependent precocious puberty (CPP). There will be no response or a FSH predominant response in gonadotropin independent precocious puberty.

In the absence of this investigation a FSH/LH assay done at midnight will show the sleep associated rise in $\mathrm{LH}$ in CPP.

The following published data are useful in the interpretation of the gonadotrophin levels using the chemiluminescent assay:

In gonadotrophin dependent precocious puberty;

LH/FSH->1 (13)

Peak LH response > 5U/L from baseline (14)

FSH has a poor diagnostic utility (15)

Basal LH >0.1 IU/L was diagnostic for CPP with 94\% sensitivity and $88 \%$ specificity (16).

4. Ultrasound scan of the abdomen (USS)

This is a useful investigation to differentiate CPP from gonadotrophin independent puberty.

- In CPP uterine length ranges from $3.4-4 \mathrm{~cm}$ and the range of ovarian volume is between $1-3 \mathrm{ml}$ in (18).

- Endometrial echo is $100 \%$ specific but less sensitive (42-87\%) in differentiating CPP (18).

- Adrenal hypertrophy will be seen in precocious puberty due to $\mathrm{CAH}$.

- Multicystic ovaries will be seen in hypothyroidism.
5. When clinically indicated adrenal androgens or thyroid function tests are useful to identify the cause of gonadotrophin independent precocious puberty.

6. Magnetic resonance image (MRI)

Hypothalamic hamartoma is the commonest central nervous system pathology associated with CPP.

All boys with CPP and girls $<6$ years should have an MRI of the brain. It is questionable whether it is useful in girls between $6-8$ years.

It is useful to know that the size of the pituitary is large for the chronological age in CPP; correlates with LH/ FSH ratio as this knowledge will avoid misdiagnosis of pituitary adenoma (19).

7. Insulin like growth factor (IGF1)

This is not a routine investigation. But it has been found to be raised in CPP (20).

\section{Management}

Treatment with a gonadotrophin releasing hormone $(\mathrm{GnRH})$ analogue is only effective in gonadotrophin dependent precocious puberty. Initially the progression of puberty can wax and wane. Therefore in the absence of an identifiable central nervous system pathology and a rapid progression of symptoms and signs, treatment can be withheld with close monitoring of the patient.

Local sterile abscess, hot flushes with headache, weight gain and mild hypersensitivity reactions are the reported side effects which occur rarely.

Pubertal staging and growth velocity need monitoring every 3-6 months. Reduction of breast or testicular size may be noted on follow up.

The decision to stop treatment is based on the age of puberty of peers, siblings and parents and wishes of the patient and family. Discontinuation of treatment at chronological age 11 years (bone age 12) has been associated with maximal adult height (21). It is not recommended to continue treatment beyond $12-12.5$ years of chronological age.

Once treatment is stopped menstruation will commence 2-61 months later (22).

The decision to commence treatment therefore would depend on the rapidity of the progression of puberty, the presence of CNS pathology and the age of the child. The short and long term implications of treatment should be discussed with the parents prior to treatment.

The treatment is with a long acting GnRH analogue. There are several subcutaneous and intramuscular preparations and in addition an intranasal preparation. 
In a girl the treatment is combined with norethisterone for initial 1-2 weeks to prevent withdrawal bleeding.

A height loss of $20 \mathrm{~cm}$ in boys and $12 \mathrm{~cm}$ in girls has been documented in untreated patients (23). Girls $<6$ years gain a greater benefit from treatment (24). Girls between 6-8 years may have a modest benefit. It is necessary to discuss with the family in borderline cases before commencing treatment. All boys $<9$ years with compromised adult height warrant treatment. Treatment solely for psychological reasons or cessation of menses should be individually assessed.

\section{Long term effects}

$\mathrm{BMD}$ reduces during therapy but once the treatment is discontinued normal peak bone mass is gained provided they have an adequate calcium and vitamin D intake. GnRH therapy is associated with an increased risk of PCOS (25). Long term studies have revealed that GnRH therapy has no adverse effect on fertility (26).

Psychological support should be offered to the parents and child if needed.

\section{Gonadotrophin independent precocious puberty}

\section{McCune-Albright syndrome (MAS)}

MAS is defined as a triad of precocious puberty, fibrous dysplasia of bones, and café-au-lait macules caused by an activating mutation of the GNAS1 gene. Precocious puberty is the most common endocrine abnormality though rare in males. GnRH analogues are ineffective as a treatment. Aromatase inhibitor, anastrozole has been used with success and tamoxifen, an antiestrogen has been found to be beneficial in girls. The use of testolactone in combination with spironolactone or flutamide appears to be effective in boys (27). Third generation aromatase inhibitor letrozole has been shown to be effective in treating girls with MAS even though ovarian enlargement or cyst formation may be seen in patients on higher doses (28).

\section{Testotoxicosis (Familial male precocious puberty)}

Testotoxicosis occurs due to a heterozygous mutation of the luteinizing hormone receptor gene resulting in constitutive activation of the $\mathrm{LH}$ receptor giving rise to autonomous Leydig cell hyper function. Affected boys generally present before 4 years of age. Testolactone and spironolactone have been shown to be effective in the long term treatment (29). Combined therapy with a third generation aromatase inhibitor (anastrazole) and the selective anti-androgen bicalutamide (non-steroidal antiandrogen) was used with promising results in the recent past (30).

\section{Variants of puberty}

a. Premature thelarche

Premature breast development before 3 years of age is defined as premature thelarche which may be unilateral or bilateral. Puberty occurs at the normal age and there is no advance in the bone age. The condition spontaneously resolves by 4 years of age.

The larche variant

The Majority of these patients present between 7-8 years of age. They have an advanced bone age and an increase in the height velocity. They do not need treatment and the final adult height is not affected.

\section{b. Premature adrenarche}

Premature adrenarche is defined as the presence of secondary sexual hair in girls $<8$ years and boys $<9$ years. This is more frequently seen in girls and in children from African or Indian origin. CAH and adrenal tumour need exclusion before the diagnosis of premature adrenarche is made. This may be associated with low birth weight, insulin resistance and PCOS. No specific treatment is needed and their final height is normal.

c. Isolated menarche

Isolated menarche is a benign self-limiting condition. They present with recurrent vaginal bleeding without secondary sexual characteristics. A localised lesion of the genital tract, McCuneAlbright syndrome, exogenous administration of oestrogens and child abuse need exclusion. There are no long term sequelae associated with this condition.

\section{References}

1. Parent AS, Teilmann G, Juul A, Skakkebaek NE, Toppari J, Bourguignon JP. The timing of normal puberty and the age limits of sexual precocity: variations around the world, secular trends, and changes after migration. Endocr Rev 2003; 24: 668-93.

2. He Q, Karlberg J. BMI in childhood and its association with height gain, timing of puberty, and final height. Pediatr Res 2001; 49(2): 244-51.

3. Frisch RE, Revelle R, Cook S. Components of weight at menarche and the initiation of the adolescent growth spurt in girls: estimated total water, lean body weight and fat. Hum Biol. 1973; 45(3): 469-83.

4. Moisan J, Meyer F, Gingras S. Diet and age at menarche. Cancer Causes Control 1990; 1(2): 149-54.

5. Messager S, Chatzidaki EE, Ma D, et al. Kisspeptin directly stimulates gonadotropin-releasing hormone release via G protein-coupled receptor 54. Proc. Natl. Acad. Sci. U.S.A 2005; 102(5): 1761-6. 
6. Elias CF. Leptin action in pubertal development: recent advances and unanswered questions. Trends Endocrinol Metab 2012; 23(1): 9-15.

7. Wyshak G, Frisch RE. Evidence for a secular trend in age of menarche. N Engl J Med 1982; 306(17): 1033-5.

8. Kaplowitz PB, Oberfield SE. Reexamination of the age limit for defining when puberty is precocious in girls in the United States: implications for evaluation and treatment. Pediatrics 1999; 104: 936-41.

9. Midyett LK, Moore WV, Jacobson JD. Are pubertal changes in girls before age 8 benign? Pediatrics 2003; 111: 47-51.

10. Browne LP, Boswell HB, Crotty EJ, O’Hara SM, Birkemeier KL, Guillerman RP. Van Wyk and Grumbach syndrome revisited: imaging and clinical findings in preand postpubertal girls. Pediatr Radiol 2008 ; 38(5): 538-42.

11. Paediatric Endocrinology. Sperling MA- 3rd edition.

12. Bidlingmaier F, Butenandt O, Knorr D. Plasma gonadotropins and estrogens in girls with idiopathic precocious puberty: Pediatr Res 1977; 11(2): 91-4.

13. Pescovitz OH, Hench KD, Barnes KM, Loriaux DL, Cutler GB Jr. Premature thelarche and central precocious puberty: the relationship between clinical presentation and the gonadotropin response to luteinizing hormone-releasing hormone. J Clin Endocrinol Metab 1988; 67: 474-9.

14. Neely EK, Hintz RL, Wilson DM, et al. Normal ranges for immunochemiluminometric gonadotropin assays. J Pediatr 1995; 127: 40-6.

15. Cavallo A, Richards GE, Busey S, Michaels SE. A simplified gonadotrophin-releasing hormone test for precocious puberty. Clin Endocrinol (Oxf) 1995; 42: 641-6.

16. Neely EK, Wilson DM, Lee PA, Stene M, Hintz RL. Spontaneous serum gonadotropin concentrations in the evaluation of precocious puberty. J Pediatr 1995; 127: 47-52.

17. Carel JC, Eugster EA, Rogol A, Ghizzoni L, Palmert MR. Consensus statement on the use of gonadotropin-releasing hormone analogs in children. Pediatrics 2009; 123: 752-62.

18. de Vries L, Horev G, Schwartz M, Phillip M. Ultrasonographic and clinical parameters for early differentiation between precocious puberty and premature thelarche. Eur J Endocrinol 2006; 154(6): 891-8.

19. Pérignon F, Brauner R, Argyropoulou M, Brunelle F. Precocious puberty in girls: pituitary height as an index of hypothalamo-pituitary activation. J Clin Endocrinol Metab 1992; 75(4): 1170-2.
20. Belgorosky A, Rivarola MA. Irreversible increase of serum IGF-1 and IGFBP-3 levels in GnRH-dependent precocious puberty of different etiologies: implications for the onset of puberty. Horm Res 1998; 49(5): 226-32.

21. Arrigo T, Cisternino M, Galluzzi F, et al. Analysis of the factors affecting auxological response to GnRH agonist treatment and final height outcome in girls with idiopathic central precocious puberty. Eur J Endocrinol 1999; 141(2): 140-4.

22. Cassio A, Bal MO, Orsini LF, et al. Reproductive outcome in patients treated and not treated for idiopathic early puberty: long-term results of a randomized trial in adults. $J$ Pediatr 2006; 149(4): 532-6.

23. Carel JC, Lahlou N, Roger M, Chaussain JL. Precocious puberty and statural growth. Human Reproduction Update 2004; 10: 135-47.

24. Lazar L, Padoa A, Phillip M. Growth pattern and final height after cessation of gonadotropin-suppressive therapy in girls with central sexual precocity. J Clin Endocrinol Metab 2007; 92(9): 3483-9.

25. Chiavaroli V, Liberati M, D’Antonio, et al. GNRH analog therapy in girls with early puberty is associated with the achievement of predicted final height but also with increased risk of polycystic ovary syndrome. Eur J Endocrinol 2010; 163: 55-62.

26. Heger S, Müller M, Ranke M, et al. Long-term GnRH agonist treatment for female central precocious puberty does not impair reproductive function. Mol Cell Endocrinol 2006; 254-255: 217-20.

27. Zacharin M. Paediatric management of endocrine complications in McCune-Albright syndrome. J Pediatr Endocrinol Metab 2005; 18: 33-41.

28. Feuillan P, Calis K, Hill S, et al. Letrozole Treatment of Precocious Puberty in Girls with the McCune-Albright Syndrome: A Pilot Study. J Clin Endocrinol Metab 2007; 92: 2100-6.

29. Leschek EW, Jones J, Barnes KM, Hill SC, Cutler GB Jr. Six-year results of spironolactone and testolactone treatment of familial male-limited precocious puberty with addition of deslorelin after central puberty onset. J Clin Endocrinol Metab 1999; 84: 175-8.

30. Kreher NC, Pescovitz OH, Delameter P, Tiulpakov A, Hochberg Z. Treatment of familial male-limited precocious puberty with bicalutamide and anastrozole. J Pediatr 2006; 149: 416-20. 